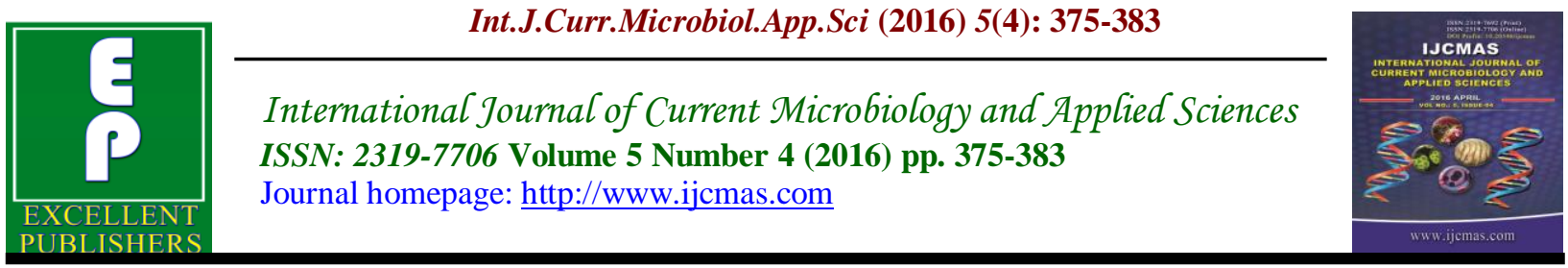

Review Article

http://dx.doi.org/10.20546/ijcmas.2016.504.045

\title{
Biodegradation of Heavy Metals - A Review
}

\author{
P.Meenambigai ${ }^{1}$, R. Vijayaraghavan ${ }^{2}$, R. Shyamala Gowri ${ }^{1}$, \\ P.Rajarajeswari ${ }^{1}$ and P. Prabhavathi ${ }^{3 *}$ \\ ${ }^{1}$ Department of Microbiology and Biochemistry, Nadar Saraswathi College of \\ Arts \& Science, Theni, Tamil Nadu, India \\ ${ }^{2}$ Department of Microbiology and Nanotechnology, Nehru Arts \& Science College, \\ Coimbatore. Tamil Nadu, India \\ ${ }^{3}$ Department of Microbiology, PSG College of Arts and Science, Coimbatore-14, \\ Tamil Nadu, India \\ *Corresponding author
}

\begin{abstract}
A B S T R A C T
Keywords

Heavy Metals, Radionuclide, Bioremediation, Soil.

\section{Article Info}

Accepted:

15 March 2016

Available Online:

10 April 2016

Soil is the soul of immeasurable life. It is being polluted by various organic and inorganic pollutants due to hasty urbanization and industrialization; it has led to increased dumping of heavy metals and radionuclide into the surroundings. Remediation is a main solution to solve the problem. There is a critical need for sprouting a comprehensive soil protection policy based on precautionary, analytical and therapeutic instruments, which are legally implemented. Restrictive and clean up measures to avoid hazards from contaminated soil belong to the curative soil protection. Bioremediation is a method, which uses indigenous micro flora or added specific microorganisms to help in biodegradation of pollutants and recovery of land and ground water. There are also numerous constraints, which should be overcome to use their method successfully as a tool for remediation of contaminated soils. When a microbiological methods are used to remove the complex polymers into the less dangerous forms are known as biodegradation, and in turn utilized by them as a source of energy.
\end{abstract}

\section{Introduction}

Soil is an only habitat which contains a variety of microflora and fauna it gives mechanical and nutritional support to higher plants. Heavy metals are widely used in the industries like, textile, leather, paper, electroplating, chrome plating, petroleum refining, paint, fabricating Industries. These industries discharge large quantities of toxic waste and the untreated effluents to the environment and cause a serious ecological contamination (Wang, 2002). The concern presence, deposition and persistence of organic pollutants in the environment cause soil, water and air contamination.

Metals discharged into the water bodies, undergo chemical transformation and creating larger impact to the environment 
and human health (Volesky, 1993).

Soil contamination by the heavy metals is the critical environmental problem and poses significant impacts to the ecosystem. Heavy metals presence in the soil, subsequently enters in to the human food through plants and cause risk and they tend to transferred from one food chain to another. Through anthropogenic activities the industries discharge a variety of heavy metals like cadmium, nickel, chromium, lead, arsenic, mercury of heavy metals in trace amount causes toxic to flora and fauna. (Nilanjana Das et al., 2008).

Now a day there are numerous new technologies were developed these emphasize the destruction of the pollutants rather than conventional approach of disposal.

Several waste water technologies were used in target scale, to reduce the concentration of hazardous compounds in waste water from higher level to lower level (Verma and Rahal, 1996).

The contamination of soil has been remediated by the physical, chemical degradation, photo degradation and microbial degradation. These methods have some drawbacks in completely remediating hydrocarbon contaminated soil and cause more toxic to the environment (Garsibu et al., 2003).

Biological treatment is one of the best methods for remediating heavy metal contaminated soil it utilizes the indigenous microorganisms in the soil and remediate the heavy metals in to innocuous substances (Table 1).

Metal contaminated soil can be remediated by chemical, physical and biological techniques. These can be grouped into two categories (Baker et al., 1990) (Table 2).

\section{Ex - situ Method}

Ex situ method applied for remediating the polluted soil. It requires a contaminated soil for the remediating by excavation and detoxification or destruction of physical and chemical contaminant. As a result contaminant undergoes stabilization, solidification and immobilization.

\section{In-Situ method}

Reed et al. (1992) defined as In situ method are used for destruction or transformation of the contaminants. Immobilize to reduce bioavailability and the separation of the contamination. The physico - chemical methods for soil remediation render the growth of plants and remove all biological activities and microbes such nitrogen fixing bacteria, fungi as well as fauna (Burns et al., 1996).

\section{Phytoremediation}

Phytoremediation is a remediation method that utilizes plants to remove, or to detoxify environmental contaminats (Palmorth, 2006). Phytoremediation includes the following techniques such as Rhizofiltration, Phytostabilizaton, Phytoextration, phytovolatilization and Phytotransformation (Ghosh and Singh, 2003).

\section{Phytostabilization}

Plants are grown in the land, to stabilize the soil and to reduce bioavailability of metals. Plants need to be tolerant of metals in this case, accumulation may became disadvantage to the environment (Latha et al., 2004). 


\section{Rhizofiltration}

The roots of plants are used to adsorb the metals from a contaminated soil or solution and the metals removed by harvesting the whole plant. In this case tolerance and translocation are largely irrelevant (Latha $e t$ al., 2004).

\section{Phytoextraction}

Plants can be grown on contaminated soil and the aerial plants are harvested. In this case plants need to be tolerant only if the soil metal content is very high, but they need to accumulate very high concentrations in their aerial parts and in practice need to be hyper accumulator.

Now a days several methods are used for the removal of heavy metals. This includes chemical precipitation, ion exchange, electrochemical treatment, membrane technologies, adsorption on activated carbon etc (Matheickal et al., 1999). Each of these has its own advantages and disadvantages (Table 3). Among them chemical precipitation and electrochemical treatments method are more ineffective, while the metal ion concentration is low. Ion exchange and activated carbon adsorption processes are extremely more expensive than other methods. The removal of heavy metals from waste waters has been directed towards bioremediation (Nilanjana Das et al., 2008).

\section{Bioremediation Techniques}

Bioremediation is a process used to detoxify or to remove organic and inorganic xenobiotics present in the environment. Remediation process is the solution for the problem of heavy metals contamination (Abioye, 2011). The main role of bioremediation is to reduce the cost. Bioremediation are effective only when the environmental conditions permit to the growth and activity of micro organism and this often involves the manipulation of the environment and allow the growth of microorganism (Vidali, 2001).

Microorganisms play a vital role in bioremediation of heavy metal from the contaminated soil and waste water. Though when microorganisms especially bacteria are exposed to higher concentration of metal, it may have cidal effects on them. Microorganisms can interact with metals and radionuclides via many mechanisms, some of which may be used as the basis for potential bioremediation strategies (Lloyd et al., 2005). Mechanisms by which microorganisms act on heavy metals includes biosorption (metal sorption to cell surface by physico chemical mechanisms), bioleaching (heavy metal mobilization through the excretion of organic acids or methylation reactions), biomineralization (heavy metal immobilization through the formation of insoluble sulfides or polymeric complexes) intracellular accumulation and enzyme catalyzed transformation (Lloyd, 2002).

\section{Biostimulation}

Biostimulation is a bioremediation mostly used for the remediation of contaminated soil. This includes the addition of nutrients, either organic or inorganic to enhance the activity of microbes. Treatment of carbon source such as $\mathrm{N}$ and $\mathrm{P}$. This involves in the stimulation of biodegradation and these were often estimated as $\mathrm{C} / \mathrm{N}$ ratios (SangHwan et al., 2007)

Carbon sources are added as a nutrient in contaminated soil to enhance the rate of pollutant degradation by stimulating the growth of microorganisms which is responsible for the biodegradation of the 
pollutant. Addition of carbon in the form of pyruvate not only stimulates the growth of microorganisms it also involves to enhance the rate of PAH degradation (Lee et al., 2003).

By the use of composting bioremediation the primary, the primary ingredients of compost were mixed with the contaminated soil, the pollutants are degraded by the active microflora with in the mixture (Semple et al., 2001).

\section{Bioaugmentation}

In this approach the introduction of microorganism possess the biodegradation potential into the contaminated environment to assist the indigenous microbes. This may sometimes involved by the addition of genetically engineered microorganisms suited for biodegradation of the heavy metal contaminants. Bioaugmentation is a promising and low cost bioremediation strategy in which an effective bacterial isolates or microbial consortium capable for degrading xenobiotics were administered to the contaminated sites (Gentry et al., 2004). The bioremediation of soil contamination with heavy metal sources through bioaugmentation has been reported by various authors (Table 4).

The environment is very complicated, the degrading ability of exogenously added microorganisms tends to be affected by the physicochemical and biological features of the soil in the environment. Bioaugmentation is not an effective solution for remediation of contaminated soil because in some cases laboratory stains of microorganisms rarely growth and biodegrade xenobiotics when compared to the indigenous microbes (Thieman and Pallandino, 2009).

\section{Factors Affecting Biosorption}

The major factors that affect the biosorption process are (i) initial metal ion concentration, (ii) $\mathrm{pH}$ (iii) temperature (iv) biomass concentration in solution. Aksu et al. (1992) reported that the temperature does not influence the biosorption processes in the range of $20^{\circ}$ to $30^{\circ} \mathrm{C}$. However, $\mathrm{pH}$ seems to be the most important parameter in the biosorption processes. It affects the solution chemistry of the functional groups in the biomass and the competition of the metallic ions (Friis et al., 1998). Biomass concentration in the solution seems to influence the specific uptake for lower values of biomass concentration leads to interference between the binding sites.

\section{Advantages of Biosorption}

Non - living cells are less sensitive to ion concentration (toxicity effects)

Can be operated at ambient conditions of $\mathrm{pH}$ and temperature

Low operating cost

Volume of chemical or biological sludge can be minimized

Supply of nutrients is not required

Dead biomass can also be procured from industrial sources as a waste product from the fermentation processes.

\section{Developments in Molecular Microbial Ecology}

Our current knowledge is to bring changes in microbial communities during a bioremediation process is very limited and consequently the microbial community is still treated as a "black box" (IWamoto and 
Nasu, 2001). This is mostly due to the fact that many environmental bacteria cannot yet be cultured by conventional laboratory techniques (Kogure et al., 1979). Because the bioremediation often faces the difficulty of identifying the cause and developing measures.
Now a days, the recent advances in the field of molecular biological methods are helping us to study the structure and dynamics of microbial communities without bias introduced by cultivation. These molecular biological techniques are frequently used in microbial ecological studies.

Table.1 Sources of Discharge of Metals

\begin{tabular}{|l|l|l|}
\hline S.No & $\begin{array}{l}\text { Heavy } \\
\text { metal }\end{array}$ & Source \\
\hline 1. & Lead & $\begin{array}{l}\text { Present in petro - based materials and many other manufacturing } \\
\text { amenities }\end{array}$ \\
\hline 2. & Chromium & $\begin{array}{l}\text { built-up operations together with chrome plating, petroleum refining, } \\
\text { leather, tanning, wood preserving, textile manufacturing and pulp } \\
\text { processing. It exists in both hexavalent and invalent forms. }\end{array}$ \\
\hline 3. & Zinc & $\begin{array}{l}\text { Widely used in industry to make paint, rubber, dye, wood preservatives } \\
\text { and ointments and electroplating industries. }\end{array}$ \\
\hline 4. & Nickel & Galvanized, paint and powder batteries processing units. \\
\hline \multicolumn{2}{|c|}{ Navneet Joshi (2003) } \\
\hline
\end{tabular}

Table.2 Harmful Effects

\begin{tabular}{|l|l|l|}
\hline S.No & $\begin{array}{l}\text { Heavy } \\
\text { metal }\end{array}$ & Effects \\
\hline 1. & Chromium & $\begin{array}{l}\text { Irritant, sickness and nausea, carcinogen, low level exposure can irritate } \\
\text { the skin and cause ulceration. Long term exposure can cause kidney and } \\
\text { liver damage, and damage too circulatory and nerve tissue. }\end{array}$ \\
\hline 2. & Zinc & $\begin{array}{l}\text { Nausea and vomiting. Zinc combines with other elements to form zinc } \\
\text { compounds; common zinc compounds found at hazardous waste sites } \\
\text { includes zinc chloride, zinc oxide, zinc sulphate, zinc phosphate, zinc } \\
\text { cyanide and zinc sulfide }\end{array}$ \\
\hline 3. & Lead & $\begin{array}{l}\text { Damage to nervous system, circulatory system, blood forming system, } \\
\text { reproductive system, gastrointestinal tract and kidney. Lead is known } \\
\text { for its harmful effect on the living world, enters the organism by } \\
\text { inhaling swallowing, or inclusion through the skin. The greatest hazard } \\
\text { from lead comes from its leaning to accumulate in the human organism. } \\
\text { The central nervous system is most insightful to the effects of lead. }\end{array}$ \\
\hline 4. & Nickel & $\begin{array}{l}\text { Short - term overexposure to nickel is known to cause any health } \\
\text { problems, but long-term exposure can cause decreased body weight, } \\
\text { heart and liver damage and skin irritation. The EPA does not currently } \\
\text { regulate nickel levels in drinking water. }\end{array}$ \\
\hline
\end{tabular}


Table.3 Advantages and Disadvantages of Phytoremediation

\begin{tabular}{|c|c|c|}
\hline S.No & Advantages & Disadvantages \\
\hline 1. & $\begin{array}{l}\text { Bendable to a variety of organic and inorganic } \\
\text { compounds }\end{array}$ & $\begin{array}{l}\text { Restricted to sites with trivial contamination within } \\
\text { rooting zone of remediative plants. }\end{array}$ \\
\hline 2. & $\begin{array}{l}\text { Insitu / Exsitu application possible with effluent/soil } \\
\text { substrate respectively. }\end{array}$ & $\begin{array}{l}\text { May take up to some years to remediate a } \\
\text { contaminated site. }\end{array}$ \\
\hline 3. & $\begin{array}{l}\text { In situ applications decrease the amount of soil } \\
\text { disorder compared to conventional methods }\end{array}$ & Restricted to sites with low contaminant absorptions \\
\hline 4. & $\begin{array}{l}\text { Reduces the amount of waste to be soil filled (upto } \\
95 \% \text { ), can be further employed as bio-ore of heavy } \\
\text { metals }\end{array}$ & $\begin{array}{l}\text { Harvested plant biomass from Phytoremediation may } \\
\text { be classified as a dangerous waste hence disposal } \\
\text { should be proper. }\end{array}$ \\
\hline 5. & $\begin{array}{l}\text { In situ applications decrease spread of contaminant } \\
\text { via air and water }\end{array}$ & Climatic states are a limiting factor \\
\hline 6. & $\begin{array}{l}\text { Does not need expensive equipment or highly } \\
\text { specialized personnel }\end{array}$ & $\begin{array}{l}\text { Introduction of nonnative species may affect bio } \\
\text { mixture }\end{array}$ \\
\hline 7. & $\begin{array}{l}\text { In large scale applications the prospective energy } \\
\text { stored can be utilized to create thermal energy }\end{array}$ & $\begin{array}{l}\text { Utilization/ operation of contaminated plant biomass } \\
\text { is a cause of concern. }\end{array}$ \\
\hline 8. & comparatively low cost & elongated remediation moment \\
\hline \multicolumn{3}{|c|}{ Sources: (Susarla et al., 2002, Kamath et al., 2004) } \\
\hline
\end{tabular}

Table.4 List of Metal Degrading Microorganisms

\begin{tabular}{|c|c|c|c|}
\hline S.No & Metals & Degrading Microorganisms & Reference \\
\hline 1. & $\mathrm{Cr}$ & $\begin{array}{l}\text { Pseudomonas aeruginosa, } \\
\text { Bacillus subtilis, Sacchromyces } \\
\text { cerevisiae }\end{array}$ & Fathima Benazir et al (2010) \\
\hline 2. & $\mathrm{Cd}$ & $\begin{array}{l}\text { Alcaligenes sp, Psedomonas sp, } \\
\text { Moraxella sp }\end{array}$ & Springael et al (1993) \\
\hline 3. & $\mathrm{Ni}$ & $\begin{array}{l}\text { Bacillus subtilis, } \\
\text { P. licheniformis }\end{array}$ & Holan \& Volesky (1994) \\
\hline 4. & $\mathrm{Ag}$ & Streptomyces noursei & Mattuschka et al (1993) \\
\hline 5. & $\mathrm{Au}$ & $\begin{array}{l}\text { Aspergillus niger } \\
\text { Chlorella pyrenoidosa }\end{array}$ & $\begin{array}{l}\text { Kuyucak and Volesky, } 1988 \\
\text { Darnall et al, } 1988\end{array}$ \\
\hline 6. & $\mathrm{Co}$ & Sacchromyces cerevisiae & Brady and Duncan, 1993 \\
\hline 7. & $\mathrm{Cu}$ & $\begin{array}{l}\text { Cardida tropicalis } \\
\text { Bacillus licheniformis }\end{array}$ & $\begin{array}{l}\text { Mattuschka et al (1993) } \\
\text { Beveridge, } 1986\end{array}$ \\
\hline 8. & $\mathrm{Fe}$ & Bacillus subtilis & Beveridge, 1986 \\
\hline 9. & $\mathrm{Hg}$ & Penicillum chrysogenum & Nemec et al, 1977 \\
\hline 10. & $\mathrm{Mn}$ & Bacillus licheniformis & Beveridge, 1986 \\
\hline 11. & $\mathrm{~Pb}$ & Penicillum chrysogenum & Niu et al, 1993 \\
\hline 12. & $\mathrm{U}$ & Sacchromyces cerevisiae & Volesky 1986 \\
\hline 13. & $\mathrm{Th}$ & Sacchromyces cerevisiae & Brierley et al, 1986 \\
\hline 14. & $\mathrm{Zn}$ & $\begin{array}{l}\text { Rhizopus arrhizus } \\
\text { Penicillium chrysogenum } \\
\text { Penicillum spinulosum }\end{array}$ & $\begin{array}{l}\text { Tobin et al, } 1984 \\
\text { Niu et al, } 1993 \\
\text { Townsley et al, } 1986\end{array}$ \\
\hline
\end{tabular}


The molecular methods are used to study an in situ bioremediation process for the detection and monitoring of target bacteria are the following process (i) fluorescence in situ hybridization (FISH) with rRNA targeted oligonucleotides probes (Hahn et al., 1992) and (ii) in situ PCR (Hodson et al., 1995). Denaturing gradient gel electrophoresis (DGGE) of PCR amplified $16 \mathrm{~s}$ rDNA fragments has emerged as a powerful technique for monitoring changes in bacterial diversity (Muyzer et al., 1993). Another method for the study of microbial community diversity is terminal restriction fragment length polymorphism (T-RFLP) (Liu et al., 1997)

In conclusion, Bioremediation is get to be an immature technology that needs to define its boundaries between promise and reality. It frequently addresses multiphase, heterogeneous environments (i.e., soils), bioremediation is dependent on an interdisciplinary approach involving such disciplines as microbiology, engineering, ecology, geology and chemistry. The interdisciplinary approach is also required because of the complexity encountered in the type and extent of contamination and the social and legal issues of relevant to most contaminated sites.

Through improved understanding of the ecology, physiology, evolution, biochemistry and genetics of microorganisms, the prospect are successfully stimulating and exploiting microbial metabolism for environmental purpose. Despite its limitations, the future of bioremediation appears bright as the advances in the diverse disciples that shape bioremediation.

Progress in developing strategies for in situ microbial approaches to metals remediation has clearly lagged significantly behind the development of in situ bioremediation of organics. However, and since funding opportunities for research on in situ bioremediation of metals has increased dramatically in recent years, it seems likely that novel advances in this area will be forthcoming.

Can be operated at ambient conditions of $\mathrm{pH}$ and temperature

Low operating cost

Volume of chemical or biological sludge can be minimized

Supply of nutrients is not required

Dead biomass can also be procured from industrial sources as a waste product from the fermentation processes.

\section{References}

Abioye, O., Peter. 2011. Biological remediation of hydrocarbon and heavy metals contaminated soil. Soil Contamination, 7: 127-142.

Aksu, Z., Sag, Y., Kutsal, T. 1992. The biosorption of copper by C.vulgaris and Z.ramigera, Environ. Technol., 13: 579586.

Baker, A.J.M., Wlaker, P.L. 1990. Heavy metal tolerance in plants: Evolutionary Aspects. (ed shaw AJ) - Boca Raton: CRC Press, 155-157.

Beveridge, T.J. 1986. The immobilization of soluble metals by bacterial walls. Biotechnology and Bioengineering Symposium. 127-140.

Brady, D., Duncan, J.R. 1993. Bioaccumulation of metal cations by Sacchromyces cerevisiae. BioHydroMetallurgical Technologies; Torma A.E., Apel, M.L., 2: 711-724.

Burns, R.G.S., Rogers, S., McGhee, I. 1996. contamination and the soil Environment 
in the Australia Pacific Region. (ed. Nidu, R., Kookana., R.S., Oliver, D.P., Rogers S. and McLaughlin M.J.) - Kluwer Academic Publishers, London. 361-440.

Darnall, D.W., Greene, B., Gardea Torresday, J. 1988. Gold binding to algae. BioHydroMetallury, 487-498.

Fathima Benazir, J., Suganthi, R., Rajvel, D., Padmini Pooja, M., Mathitumilan, B. 2010. Bioremediation of chromium in tannery effluent by microbial consortia. African J. Biotechnol., 9(21): 3140-3143.

Friis, M., Keith, M. Biosorption of Uranium and lead by Streptomyces longwoodensis, Biotechnol. Bioenergy, 35: 320-325.

Garbisu, C., Alkorta. 2003. Basic concepts on heavy metal soil bioremediation. The European J. Mineral Processing and Environ. Protection, 3: 58-66.

Gentry, T.J., Rensing, C., Pepper, I.L. 2004. New approaches for bioaugmentation as a remediation technology. Critical Rev. Environ. Sci. Technol., 34: 447-494.

Ghosh, M., Singh, S.P., Purohit, S.B. 2003. Comparative uptake and Phytoextraction by accumulator and weed species.

Hahn, D., Amann, R.I., Ludwig, W., Akkermans, A.D.L., Schleifer, K.H. 1992. Detection of microorganisms in soil after Insitu hybridization with rDNA targeted, fluorescently labeled oligonucleotides. J. Gen. Microbiol., 138: 879-887.

Hodson, R.E., Dustwan, W.A., Garg, R.P., Moran, M.A. 1995. Insitu PCR for visualization of microscale distribution of specific genes and gene products in prokaryotic communities. Appl. Environ. Microbiol., 61: 4074-4082.

Holan, Z., Volesky, B., Prasetyo, I. 1994. Biosorption of cadmium by biomass of marine algae. Biotechnol. Bioenerg., 43: 1001-1009.

Iwamoto, T., Nasu, M. 2001. Current bioremediation practice and perspective. J. Biosci. Bioengi., 92: 1-8.

Kamath, R., Rentz, J.A., Schinoor, J.L., Alvarez, P.J.J. 2004. Phytoremediation of hydro - carbon contaminated soils:
Principles and applications. In: Petroleum biotechnology development and perspectives. Vazquez - Duhalt, $\mathrm{R}$ and Quintero - Ramirez R. (eds) Elsevier, Amsterdam, 447-478.

Kogure, K., Simidzu, U., Taga, T. 1979. A tentative direct microscopic method for counting living marine bacteria. Can. J. Microbiol., 25: 415-420.

Kuyucak, N., Volesky, B. New algal biosorbent for a gold recovery process. Biohydrometallurgy. Proceedings of the Int. Symposium, 453-464.

Latha, M.R., Indirani, R., Kamaraj, S. 2004. Bioremediation of polluted soil. Agri. Rev., 25(4): 252-266.

Lee, K., Park, J.W., Ahn, I.S. 2003. Effect of additional carbon source on naphthalene biodegradation by Pseudomonas putida G7, J. Hazardous Materials, 105: 157167.

Liu, W., Marsh, T.L., Cheng, H., Forney, L.J. 1997. Characterization of microbial diversity by determining terminal restriction fragment length polymorphisms of gene encoding 16s rRNA. Appl. Environ. Microbiol., 63: 4516-4522.

Lloyd, J.R. 2002. Bioremediation of metals: The application of microorganisms that make and break minerals. Microbiol. Today, 29: 67-69.

Lloyd, J.R., Anderson, R.T., Macaskie, L.E. 2005. Bioremediation of metals and radionuclides, Bioremediation applied microbial solutions for real world environmental cleanup. Atlas R.M and Philip J.C., (eds) ASM Press, ISBN 155581- 239 -2, Washington, D.C 294.

Matheickal, J.T., Yu, Q. 1999. Biosorption of lead (II) and copper (II) from aqueous solution by pretreated biomass of Australian marine algae. Biores. Technol., 69: 223-229.

Mattuschka, B., Junghaus, K., Straube, G. 1993. Biosorption of metals by waste biomass. Biohydromettallurgical Technol., 2: 125-132.

Muyzer, G., de wall, E.C., Uitterlinden, A.G. 
1993. Profilling of complex microbial populations by denaturing gradient gel electrophoresis analysis of polymerase chain reaction - amplified genes coding for 16s rRNA. Appl. Environ. Microbiol., 59: 695-700.

Navneet Joshi. 2003. Biosorption of heavy metals.

Nemec, P., Prochazka, H., Stamberg, K., Katzer, J., Stamberg, J., Jilek, R., Hulak, P. 1977. Process of treating mycelia of fungi for retention of metals. U.S.Patent, 4: 021-368.

Nilanjana Das, R., Vimala, Karthika, P. 2008. Biosorption of heavy metals - an overview. Indian J. Biotechnol., 7: 15969.

Niu, H., Xu, X.S., Wang, J.H., Volesky, B. 1993. Removal of lead from aqueous solutions by Penicillum biomass. Biotechnol. Bioenerg., 42: 785-787.

Palmroth, M.R.T., Pichtel, J., Puhakka, J.A. 2002. Phytoremediation of subarctic soil contaminated with diesel fuel. Biores. Technol., 84: 221-228.

Reed, D.T., Tasker, I.R., Cunnane, J.C., Vandergrft, G.F. 1992. Environmental remediation removing organic and metal ion pollutants. Amer. Chem. Soc., Washington DC, 1-19.

Sang-Hwan, L., Seokho, L., Dae-Yeon, K. 2007. Degradation characteristics of waste lubricants under different nutrient conditions. J. Hazardous Materials, 143: 65-72.

Semple, K.T., Reid, B.J., Fermor, T.R. 2001. Impact of composting strategies on the treatment of soils contaminated with organic pollutants: a review. Environ.
Poll., 112: 269-283.

Springael, D., Diets, L., Hooyberghs, L., Krepsk, S., Mergeay, M. 1993. Construction and Characterization of heavy metal resistant halo aromatic degrading Alcaligenes eutrophs strains. Appl. Environ. Microbiol., 59: 334-339.

Susarla, S., Medina, V.F., McCutcheon, S.C. 2002. Phytoremediation: an ecological solution to organic chemical contamination. Ecol. Engi., 18: 647-658.

Thieman, W.J., Palladino, M.A. 2009. Introduction to biotechnology, $2^{\text {nd }}$ edition. Pearson, New York, 209-222.

Tobin, J.M., Cooper, D.G., Neufeld, R.J. 1984. Uptake of metal ions by Rhizopus arrihus biomass. Appl. Environ. Microbiol., 47: 821-824.

Townsley, C.C., Ross, I.S., Atkins, A.S. 1986. Biorecovery of metallic residues from various industrial effluents using filamentous fungi. Fundamental and applied BioHydroMetallurgy; Lawrence R.W., Branion, R.M.R., Ebner, H.G., Eds; Elsevier: Amsterdam, 279-289.

Verma, N., Rahal, R. 1996. Removal of chromium by Albizia libbeck pods from industrial waste water. J. Indian Poll. Control, 12: 55-59.

Vidali, M. 2001. Bioremediation: an overview Pure and Applied Chemistry, 73(7): 1163-1172.

Volesky, B. 1986. Biotechnological Bioenergy symptoms. Biosorbent Materials, 121126.

Wang, J.L. 2002. Immobilization techniques for biocatalysts and water pollution control Science Press, Beijing.

\section{How to cite this article:}

Meenambigai, P., R. Vijayaraghavan, R. Shyamala Gowri, P. Rajarajeswari and Prabhavathi, P. 2016. Biodegradation of Heavy Metals - A Review. Int.J.Curr.Microbiol.App.Sci. 5(4): 375383. http://dx.doi.org/10.20546/ijcmas.2016.504.045 